\title{
Leaching Chalcocite in Chloride Media-A Review
}

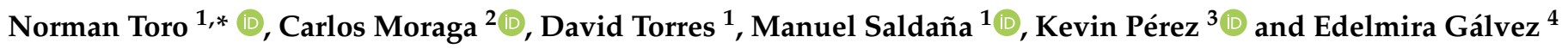 \\ 1 Faculty of Engineering and Architecture, Universidad Arturo Prat, Iquique 1100000, Chile; \\ dtorres.albornoz@gmail.com (D.T.); manuel.saldana@ucn.cl (M.S.) \\ 2 Escuela de Ingeniería Civil de Minas, Facultad de Ingeniería, Universidad de Talca, Curicó 3340000, Chile; \\ carmoraga@utalca.cl \\ 3 Departamento de Ingeniería Química y Procesos de Minerales, Universidad de Antofagasta, \\ Antofagasta 1270300, Chile; kevin.perez.salinas@ua.cl \\ 4 Departamento de Ingeniería Metalúrgica y Minas, Universidad Católica del Norte, \\ Antofagasta 1270709, Chile; egalvez@ucn.cl \\ * Correspondence: notoro@unap.cl; Tel.: +56-975387250
}

Citation: Toro, N.; Moraga, C.; Torres, D.; Saldaña, M.; Pérez, K.; Gálvez, E. Leaching Chalcocite in Chloride Media-A Review. Minerals 2021, 11, 1197. https://doi.org/ $10.3390 / \min 11111197$

Academic Editors: Kyoungkeun Yoo, Shuai Wang, Xingjie Wang and Jia Yang

Received: 26 September 2021

Accepted: 24 October 2021

Published: 28 October 2021

Publisher's Note: MDPI stays neutral with regard to jurisdictional claims in published maps and institutional affiliations.

Copyright: (c) 2021 by the authors. Licensee MDPI, Basel, Switzerland. This article is an open access article distributed under the terms and conditions of the Creative Commons Attribution (CC BY) license (https:// creativecommons.org/licenses/by/ $4.0 /)$.

\begin{abstract}
Chalcocite is the most abundant secondary copper sulfide globally, with the highest copper content, and is easily treated by conventional hydrometallurgical processes, making it a very profitable mineral for extraction. Among the various leaching processes to treat chalcocite, chloride media show better results and have a greater industrial boom. Chalcocite dissolution is a two-stage process, the second being much slower than the first. During the second stage, in the first instance, it is possible to oxidize the covellite in a wide range of chloride concentrations or redox potentials (up to $75 \%$ extraction of $\mathrm{Cu}$ ). Subsequently, $\mathrm{CuS}_{2}$ is formed, which is to be oxidized. It is necessary to work at high concentrations of chloride $(>2.5 \mathrm{~mol} / \mathrm{L})$ and/or increase the temperature to reach a redox potential of over $650 \mathrm{mV}$, which in turn decreases the thickness of the elemental sulfur layer on the mineral surface, facilitating chloride ions to generate a better porosity of this. Finally, it is concluded that the most optimal way to extract copper from chalcocite is, during the first stage, to work with high concentrations of chloride (50-100 g/L) and low concentrations of sulfuric acid $(0.5 \mathrm{~mol} / \mathrm{L})$ at a temperature environment, as other variables become irrelevant during this stage if the concentration of chloride ions in the system is high. While in the second stage, it is necessary to increase the temperature of the system (moderate temperatures) or incorporate a high concentration of some oxidizing agent to avoid the passivation of the mineral.
\end{abstract}

Keywords: $\mathrm{Cu}_{2} \mathrm{~S}$; $\mathrm{CuS}$; dissolution; chloride

\section{Introduction}

Most of copper minerals correspond to sulfide minerals and a minor part to oxidized minerals. Chalcopyrite is the most abundant among the sulfide copper minerals [1-4]. However, this mineral is refractory to conventional leaching processes due to forming a passivating layer that prevents contact between the mineral and the leaching solution [5-7]. Positive results have only been achieved for this mineral when working at medium-high temperatures (over $60^{\circ} \mathrm{C}$ ); therefore, it has not been possible to implement it on a large scale in industrial heap leaching processes [8].

In the natural mineral, chalcopyrite is commonly associated with secondary sulfides that include chalcocite $\left(\mathrm{Cu}_{2} \mathrm{~S}\right)$, digenite $\left(\mathrm{Cu}_{1.8} \mathrm{~S}\right)$, and covellite $(\mathrm{CuS})$ [9]. Chalcocite is the most abundant secondary copper sulfide, with the highest copper content, and is easily treated by hydrometallurgical processes, which makes it a very profitable mineral for its extraction [10-14]. Chalcocite has a dark gray color and belongs to the copper-rich mineral family ranging from $\mathrm{CuS}$ to $\mathrm{Cu}_{2} \mathrm{~S}$ (see Table 1), commonly found in the enriched supergenic environment below the oxidized zone of copper porphyry deposits [15-19]. This is formed by oxidation, reduction, dissemination, and migration of primary sulfides 
such as chalcopyrite [20-22], being also the main component of the tufts of copper and white metal [23-25].

Table 1. Composition, structure, and stability of minerals $\mathrm{Cu}_{\mathrm{x}} \mathrm{S}$ (Data from $[19,26]$ ).

\begin{tabular}{cccc}
\hline Mineral & Composition & System & Stability \\
\hline Chalcocite (low T) & $\mathrm{Cu}_{1.99-2} \mathrm{~S}$ & Monoclinic & $\mathrm{T}<105^{\circ} \mathrm{C}$ \\
Chalcocite (high T) & $\mathrm{Cu}_{1.98-2} \mathrm{~S}$ & Hexagonal & $\sim 105^{\circ} \mathrm{C}<\mathrm{T}<\sim 425^{\circ} \mathrm{C}$ \\
Chalcocite (high P and T) & $\mathrm{Cu}_{2} \mathrm{~S}$ & Tetragonal & $1 \mathrm{kbar}<\mathrm{P}, \mathrm{T}<500^{\circ} \mathrm{C}$ \\
Djurleite & $\mathrm{Cu}_{1.93-1.96} \mathrm{~S}$ & Monoclinic & $\mathrm{T}<93^{\circ} \mathrm{C}$ \\
Digenite (low T) & $\mathrm{Cu}_{1.75-1.8} \mathrm{~S}$ & Cubic & Metastable \\
Digenite (high T) & $\mathrm{Cu}_{1.73-2} \mathrm{~S}$ & Cubic & $83^{\circ} \mathrm{C}<\mathrm{T}$ \\
Anilite & $\mathrm{Cu}_{1.75} \mathrm{~S}$ & Orthorhombic & $\mathrm{T}<72^{\circ} \mathrm{C}$ \\
\hline
\end{tabular}

Due to the fact that hydrometallurgical processes are more economical and friendly to the environment than pyrometallurgical processes [27], and that it is relatively easy to dissolve copper from chalcocite, several investigations for the leaching of this mineral with the use of multiple additives and in different media have been carried out, such as those that include bioleaching [22,28-36], ferric sulfate solution [12,37-40], chloride medium [13,24,41-45], $\mathrm{MnO}_{2}$ as an oxidizing agent [46], pressure leaching [47,48], cyanide medium $[49,50]$, ethylenediaminetetraacetic acid (EDTA) [51,52], and synthetic chalcocite (white metal) [23,53,54].

Among the different leaching media to treat secondary copper sulfides, chloride media has had the greatest growth at an industrial level. This is not only due to the good results presented by chloride media in heap leaching processes but also due to freshwater shortage. This is due to three aspects. (i) Chlorinated media have a higher dissolution rate than traditional sulfated systems. This is due to the ability of the chloride ion to stabilize cuprous through the formation of $\mathrm{CuCl}_{3}^{2-}[8,13,43,46]$. Furthermore, the addition of chloride ions makes it possible to overcome passivation due to the formation of the sulfur layer. The chloride ions increase the redox potential, generating a thinner layer and making it easier for the chloride ions to cause porosity [55]. Figure 1 shows the effect of chloride ions in a heap leaching process at an industrial level (Chilean mine company). For an acid medium without the addition of chloride, extractions of $35 \% \mathrm{Cu}$ are obtained, while when working at 20 and $50 \mathrm{~g} / \mathrm{L}$ of chloride, extractions of $50 \%$ and $55 \% \mathrm{Cu}$ are obtained, respectively (for 90 days) [56]. (ii) It is an economic system since the chloride present in seawater $\left(20 \mathrm{~g} / \mathrm{L} \mathrm{Cl}^{-}\right)$or wastewater from desalination plants $\left(\sim 40 \mathrm{~g} / \mathrm{L} \mathrm{Cl}^{-}\right)$ can be used. (iii) Government restrictions on the use of aquifer water in large-scale mining projects. Although mining consumes much less water in its processes than other industries such as agriculture, mining deposits are generally found in arid areas where freshwater is scarce. Therefore, the use of seawater becomes practically a necessity. For example, in Chile (the largest copper producer in the world), it is projected that by 2030 seawater will represent almost $50 \%$ of the consumption of water in mining [57].

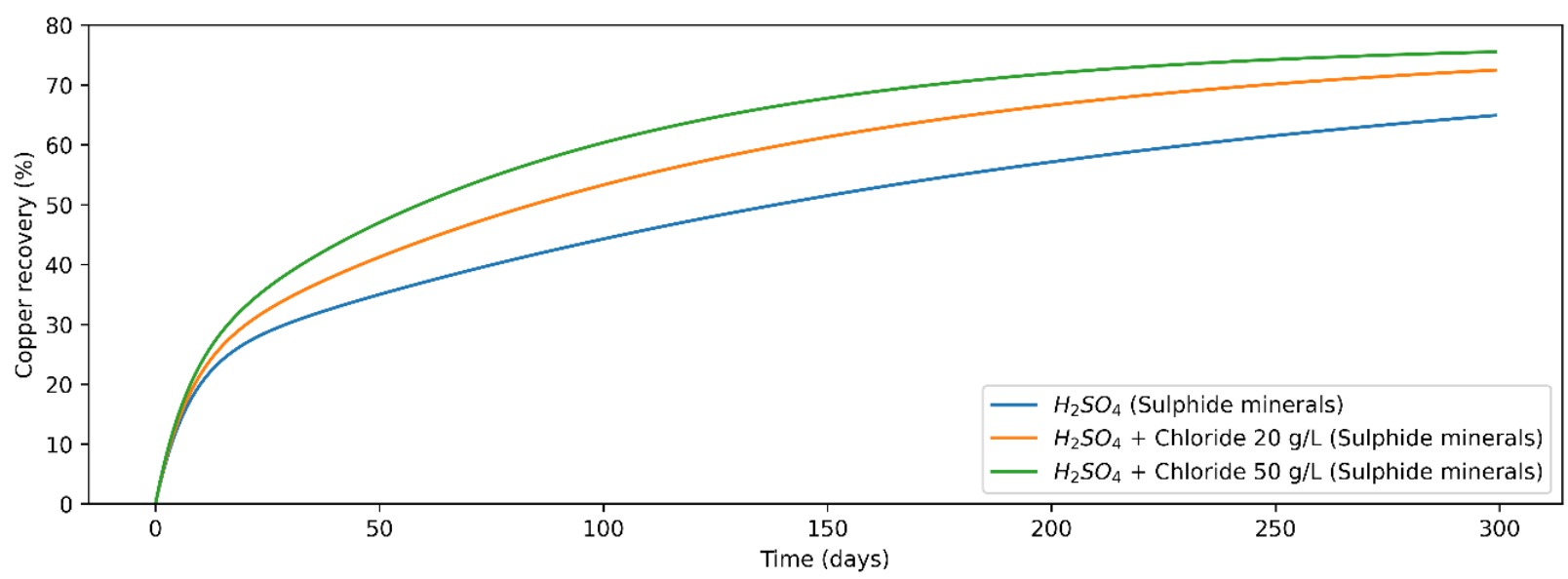

Figure 1. Extraction of copper from sulfide ores in a heap leach using $\mathrm{H}_{2} \mathrm{SO}_{4}$ and chloride (modified from: [56]). 
A bibliographic review based on scientific publications in recent years on chalcocite leaching in chloride media is carried out in the present manuscript. The objective of this work is to evaluate the different operational parameters that influence the dissolution of chalcocite, comparing the impact that each one has on the extraction of copper from it.

\section{Fundamentals}

The oxidative dissolution of chalcocite by $\mathrm{Fe}^{3+}, \mathrm{O}_{2}$, or $\mathrm{Cu}^{2+}$, either in a sulfate or chloride system, occurs in two stages (reactions 1 and 2), where the chalcocite dissolves, a progressive transformation occurs of this copper sulfide, passing through different stages called polysulfides (digenite $\mathrm{Cu}_{1.8} \mathrm{~S}$; geerite $\mathrm{Cu}_{1.6} \mathrm{~S}$; spionkopite $\mathrm{Cu}_{1.4} \mathrm{~S}$; yarrowite $\mathrm{Cu}_{1.1} \mathrm{~S}$ ), until reaching the covellite $\mathrm{CuS}[31,39,58]$. The formation of said intermediate polysulfides in the transformation of chalcocite to covellite during the first stage of leaching generates a passivating layer in the mineral particle, which can be seen in Figure 2, where said layers formed are represented. Between $10 \%$ to $20 \%$ extraction, a thin layer of covellite covers the surface of the mineral, and in the same way, but toward the interior, an intermediate layer is formed with a decreasing proportion of $\mathrm{Cu} / \mathrm{S}$. In the second leaching stage, when $49 \%$ to $55 \%$ of copper has already been extracted, the chalcocite has already been converted to covellite, and a mixture of polysulfide and sulfur is generated on the surface, while in the interior, it remains covellite and as measured. As the leaching progresses, the covellite progressively converts into sulfur and polysulfide $\left(\mathrm{CuS}_{\mathrm{n}}\right)$ with a decreasing $\mathrm{Cu} / \mathrm{S}$ ratio [42].

$$
\begin{gathered}
\mathrm{Cu}_{2} \mathrm{~S}+2 \mathrm{Fe}^{3+}=\mathrm{Cu}^{2+}+2 \mathrm{Fe}^{2+}+\mathrm{CuS} \\
\mathrm{CuS}+2 \mathrm{Fe}^{3+}=\mathrm{Cu}^{2+}+2 \mathrm{Fe}^{2+}+\mathrm{S}^{0}
\end{gathered}
$$
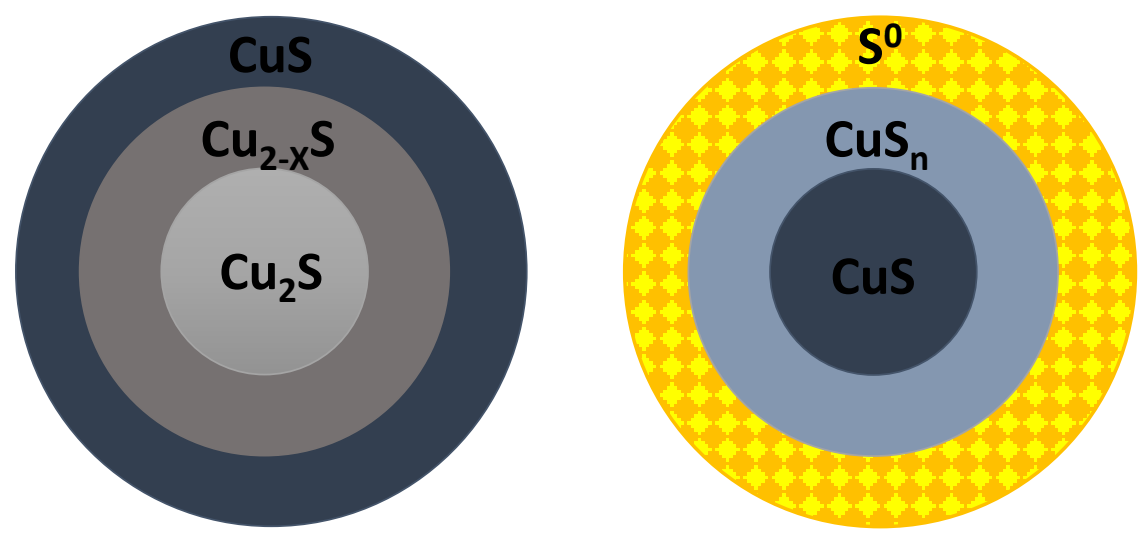

Figure 2. Graphic representation of the dissolution of the two stages of chalcocite leaching (modified from: [42]).

According to Niu et al. [39], in Equation (1) a rapid leaching occurs from chalcocite to covellite due to the low activation energy required $(4-25 \mathrm{~kJ} / \mathrm{mol})$ in the kinetic model of the unreacted nucleus, being a reaction controlled by the diffusion of the oxidant on the surface of the mineral. Meanwhile, Equation (2) shows leaching is slower and can accelerate as a function of temperature [13]. The researchers Ruan et al. [59] and Miki et al. [38] have concluded that this is because this reaction is controlled by chemical and/or electrochemical reactions under the kinetic model of the unreacted nucleus, requiring an activation energy of around $71.5-72 \mathrm{~kJ} / \mathrm{mol}$ for the transformation of covellite to dissolved copper. Nicol and Basson [60] suggest that in the oxidation of covellite, an intermediate stage occurs in which it is transformed to a polysulfide $\mathrm{CuS}_{2}$.

$$
\begin{aligned}
\mathrm{Cu}_{2} \mathrm{~S}_{2} & =\mathrm{CuS}_{2}+\mathrm{Cu}^{2+}+2 \mathrm{e}^{-} \\
\mathrm{CuS}_{2} & =\mathrm{Cu}^{2+}+2 \mathrm{~S}^{0}+2 \mathrm{e}^{-}
\end{aligned}
$$


Covellite can be oxidized over a wide range of chloride concentrations or potentials to $\mathrm{CuS}_{2}$ polysulfide (Equation (4)). Still, the oxidation of $\mathrm{CuS}_{2}$ (Equation (5)) can only occur under conditions of high chloride concentrations or high potentials (chloride concentrations greater than $2.5 \mathrm{~mol} / \mathrm{L}$ or potentials greater than $650 \mathrm{mV}$ ) [60].

For the dissolution of chalcocite in a sulfated-chloride medium, various investigations have been carried out using different additives and operational conditions (Table 2). There is a consensus in all the investigations regarding the positive effect on the dissolution kinetics of $\mathrm{Cu}_{2} \mathrm{~S}$ when adding chloride, either synthetic or using seawater. This is because chloride ions promote the formation of long crystals that allow the reagent to penetrate through the passivating layer [43].

Table 2. Comparison of previous investigations for the leaching of chalcocite in a chloride medium.

\begin{tabular}{|c|c|c|c|c|c|}
\hline Investigation & Leaching Agent & Parameters Evaluated & $\begin{array}{c}\text { Temperature } \\
\left({ }^{\circ}\right)\end{array}$ & Reference & $\begin{array}{l}\operatorname{Max} \mathrm{Cu} \\
\text { Extraction } \\
\quad(\%)\end{array}$ \\
\hline $\begin{array}{l}\text { The kinetics of leaching chalcocite } \\
\text { (synthetic) in acidic oxygenated } \\
\text { sulfate-chloride solutions }\end{array}$ & $\begin{array}{l}\mathrm{NaCl}, \mathrm{H}_{2} \mathrm{SO}_{4}, \mathrm{HCl} \\
\mathrm{HNO}_{3} \text {, and } \mathrm{Fe}^{3+}\end{array}$ & $\begin{array}{l}\text { Oxygen flow, stirring speed, } \\
\text { temperature, acid concentration, } \\
\text { ferric ion concentration, chloride } \\
\text { concentration, and particle size }\end{array}$ & $65-94$ & {$[24]$} & 97 \\
\hline $\begin{array}{l}\text { Leaching kinetics of digenite } \\
\text { concentrate in oxygenated chloride } \\
\text { media at ambient pressure }\end{array}$ & $\mathrm{CuCl}_{2}, \mathrm{HCl}$, and $\mathrm{NaCl}$ & $\begin{array}{l}\text { Effect of stirring speed, oxygen flow, } \\
\text { cupric ion concentration, chloride } \\
\text { concentration, acid concentration, } \\
\text { and temperature effect }\end{array}$ & $50-100$ & [61] & 95 \\
\hline $\begin{array}{l}\text { Leaching of sulfide copper ore in a } \\
\mathrm{NaCl}-\mathrm{H}_{2} \mathrm{SO}_{4}-\mathrm{O}_{2} \text { media with acid } \\
\text { pre-treatment }\end{array}$ & $\mathrm{NaCl}$ and $\mathrm{H}_{2} \mathrm{SO}_{4}$ & $\begin{array}{l}\text { Chloride concentration, effect of } \\
\text { agitation with compressed air, } \\
\text { percentage of solids, and particle size }\end{array}$ & 20 & [62] & 78 \\
\hline $\begin{array}{l}\text { The kinetics of dissolution of } \\
\text { synthetic covellite, chalcocite, and } \\
\text { digenite in dilute chloride solutions at } \\
\text { ambient temperatures }\end{array}$ & $\mathrm{HCl}, \mathrm{Cu}^{2+}$, and $\mathrm{Fe}^{3+}$ & $\begin{array}{c}\text { Potential redox effect, chloride } \\
\text { concentration, acid concentration, } \\
\text { temperature, dissolved oxygen, and } \\
\text { pyrite effect }\end{array}$ & 35 & [38] & 98 \\
\hline $\begin{array}{l}\text { Leaching of pure chalcocite in a } \\
\text { chloride media using seawater } \\
\text { and wastewater }\end{array}$ & $\begin{array}{l}\mathrm{NaCl}, \mathrm{H}_{2} \mathrm{SO}_{4} \text {, and } \mathrm{Cl}^{-} \\
\text {from seawater } \\
\text { and wastewater }\end{array}$ & Chloride and acid concentration & 25 & [13] & 68 \\
\hline $\begin{array}{l}\text { Modeling the kinetics of chalcocite } \\
\text { leaching in acidified cupric chloride } \\
\text { media under fully controlled pH } \\
\text { and potential }\end{array}$ & $\begin{array}{l}\mathrm{HCl}, \mathrm{CuCl}_{2}, \mathrm{NaCl}, \mathrm{KCl} \\
\mathrm{CaCl}_{2} \text {, and } \mathrm{MgCl}_{2}\end{array}$ & $\begin{array}{l}\text { Chloride concentration, cupric } \\
\text { concentration, particle size, } \\
\text { and temperature }\end{array}$ & $25-65$ & [63] & 98 \\
\hline $\begin{array}{l}\text { Leaching of pure chalcocite in a } \\
\text { chloride medium using wastewater at } \\
\text { high temperature }\end{array}$ & $\begin{array}{l}\mathrm{H}_{2} \mathrm{SO}_{4} \text { and } \mathrm{Cl}^{-} \\
\text {from wastewater }\end{array}$ & Temperature effect & $65-95$ & [43] & 97 \\
\hline $\begin{array}{l}\text { The response of the sulfur chemical } \\
\text { state to different leaching conditions } \\
\text { in chloride leaching of chalcocite }\end{array}$ & $\mathrm{FeCl}_{3}, \mathrm{CuCl}_{2}$, and $\mathrm{HCl}$ & $\begin{array}{l}\text { Chloride concentration, temperature, } \\
\text { and potential redox effect. }\end{array}$ & $35-55$ & [42] & 88 \\
\hline $\begin{array}{l}\text { Leaching of pure chalcocite with } \\
\text { reject brine and } \mathrm{MnO}_{2} \text { from } \\
\text { manganese nodules }\end{array}$ & $\begin{array}{c}\mathrm{H}_{2} \mathrm{SO}_{4}, \mathrm{MnO}_{2} \text {, and } \mathrm{Cl}^{-} \\
\text {from seawater } \\
\text { and wastewater }\end{array}$ & $\begin{array}{l}\mathrm{MnO}_{2} \text {, chloride, and } \\
\text { acid concentration }\end{array}$ & 25 & [46] & 71 \\
\hline
\end{tabular}

In a $\mathrm{Cu}_{2} \mathrm{~S}$ leaching process, adding $\mathrm{O}_{2}$ to the system at ambient pressure, with $\mathrm{H}_{2} \mathrm{SO}_{4}$ being the leaching agent, the leaching agents generated during leaching in a $\mathrm{Cu}^{2+} / \mathrm{Cl}^{-}$ system are $\mathrm{Cu}^{2+}, \mathrm{CuCl}^{+}, \mathrm{CuCl}_{2}^{-}$, and $\mathrm{CuCl}^{3-}$. The general reaction being the following:

$$
2 \mathrm{Cu}_{2} \mathrm{~S}+\mathrm{O}_{2}+4 \mathrm{H}^{+}+8 \mathrm{Cl}^{-}=4 \mathrm{CuCl}_{2}^{-}+2 \mathrm{H}_{2} \mathrm{O}+2 \mathrm{~S}^{0}
$$

Although chalcocite leaching reactions occur in two stages, guiding us to Equation (5), where the following occurs:

$$
\begin{gathered}
4 \mathrm{Cu}_{2} \mathrm{~S}+\mathrm{O}_{2}+4 \mathrm{H}^{+}+8 \mathrm{Cl}^{-}=4 \mathrm{CuCl}_{2}^{-}+2 \mathrm{H}_{2} \mathrm{O}+4 \mathrm{CuS} \\
4 \mathrm{CuS}+\mathrm{O}_{2}+4 \mathrm{H}^{+}+8 \mathrm{Cl}^{-}=4 \mathrm{CuCl}_{2}^{-}+2 \mathrm{H}_{2} \mathrm{O}+4 \mathrm{~S}^{0}
\end{gathered}
$$

By leaching $\mathrm{Cu}_{2} \mathrm{~S}$, the expected resulting products should be soluble copper such as $\mathrm{CuCl}_{2}^{-}$and a solid residue of elemental sulfur $\left(\mathrm{S}^{0}\right)$ with covellite residues or copper polysulfides $\left(\mathrm{CuS}_{2}\right)$ that still contain valuable metals. 
$\mathrm{CuCl}_{2}^{-}$is the predominant soluble species due to the complexation of $\mathrm{Cu}$ (I) with $\mathrm{Cl}^{-}$ at room temperature in a system with high chloride concentrations (greater than $1 \mathrm{~mol} / \mathrm{L}$ ). This $\mathrm{CuCl}_{2}^{-}$is stable in a potential range between $0-500 \mathrm{mV}$ and $\mathrm{pH}<6-7$ (depending on the chloride concentration in the system).

For a sulfated-chloride system where $\mathrm{MnO}_{2}$ is incorporated as an oxidizing agent, the following reactions are proposed:

$$
\begin{gathered}
2 \mathrm{Cu}_{2} \mathrm{~S}+\mathrm{MnO}_{2}+4 \mathrm{H}^{+}+4 \mathrm{Cl}^{-}=2 \mathrm{CuCl}_{2}^{-}+\mathrm{Mn}^{2+}+2 \mathrm{CuS}+2 \mathrm{H}_{2} \mathrm{O} \\
2 \mathrm{CuS}+\mathrm{MnO}_{2}+4 \mathrm{H}^{+}+4 \mathrm{Cl}^{-}=2 \mathrm{CuCl}_{2}^{-}+\mathrm{Mn}^{2+}+2 \mathrm{~S}^{0}+2 \mathrm{H}_{2} \mathrm{O}
\end{gathered}
$$

During the first leaching stage (Equation (8)), the chalcocite becomes covellite; this reaction being thermodynamically possible with a Gibbs free energy value of $-138.59 \mathrm{~kJ}$. The second reaction (Equation (9)) is slower and is also thermodynamically possible $\left(\Delta \mathrm{G}^{0}=-84.512 \mathrm{~kJ}\right)$.

\section{Operational Variables}

\subsection{Effect on Chloride Concentration}

Several authors point out that chalcocite leaching in a chloride medium is the best way to dissolve this copper sulfide $[8,13,24,38,41,63]$. Even if chloride ions are added to a chalcocite leaching with $\mathrm{H}_{2} \mathrm{SO}_{4}$ or $\mathrm{HNO}_{3}$, the kinetics increases considerably. As explained by Cheng and Lawson [24], this occurs because in leaching with only sulfate or nitrate ions, a layer of elemental sulfur is formed on the surface of the particles. In this way, an impermeable particle is generated, that is, contact between the particle with the leaching agent is prevented. This implies that the kinetics decrease in the first leaching stage and prevent the reaction in the second stage. However, when chloride ions are found, either alone or associated with sulfate or nitrate, dissolution kinetics increase along with copper extraction, as shown in Figure 3.

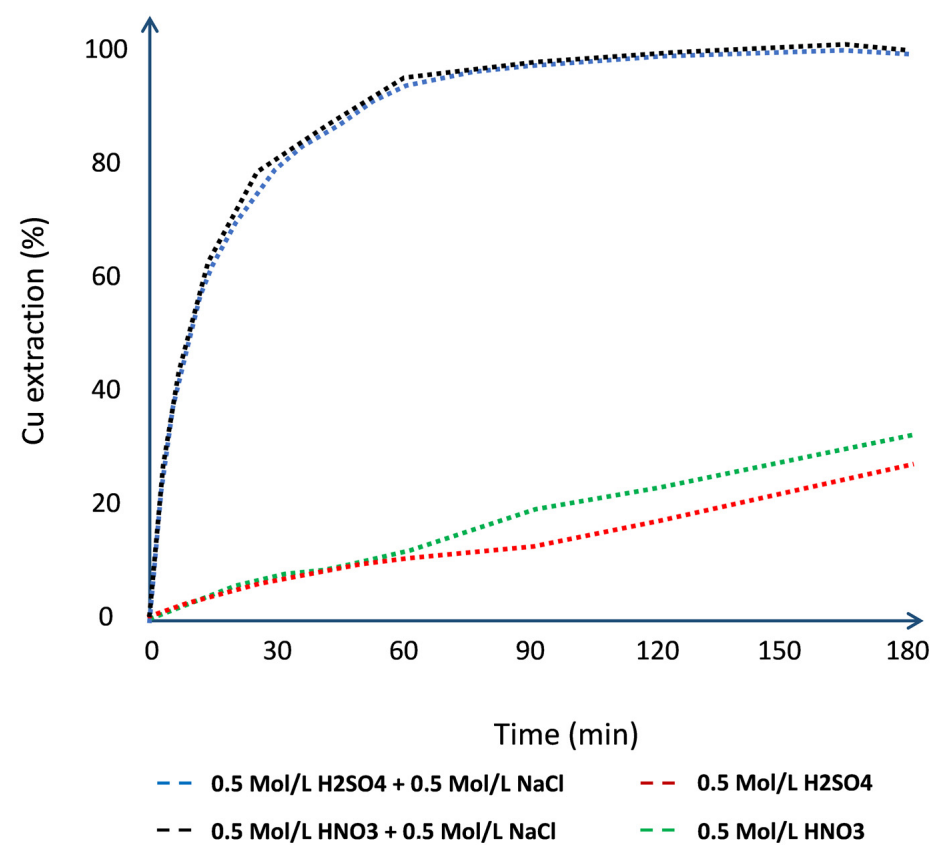

Figure 3. Effect of chloride ions on the acid leaching of chalcocite $\left(T=85^{\circ} \mathrm{C}\right.$, particle size $\left.31 \mu \mathrm{m}\right)$ (Modified from: [24]).

Several studies have shown that working at high chloride concentrations favors the leaching kinetics of secondary sulfides $[24,38,44,64]$. Chloride ions pass through the sulfur layer and generate a porous layer instead of an amorphous layer formed in the sulfate and nitrate system. The porous layer allows the entry of the leaching solution through 
said pores, thus allowing contact with the particle, thus accelerating the leaching kinetics in the first stage and making possible the dissolution reaction in the second stage of leaching $[24,65,66]$. In the study carried out by Toro et al. [13], leaching tests were carried out in stirred reactors for a pure mineral of chalcocite in an acid medium, comparing different concentrations of chloride in the system $(20,40$, and $100 \mathrm{~g} / \mathrm{L})$. In their results, the authors indicate that the highest $\mathrm{Cu}$ extractions are obtained when working at the highest chloride concentrations (see Figure 4). Furthermore, in other studies [43,46] involving the use of seawater $\left(20 \mathrm{~g} / \mathrm{L} \mathrm{Cl}^{-}\right)$and wastewater from desalination plants $\left(\sim 40 \mathrm{~g} / \mathrm{L} \mathrm{Cl}^{-}\right)$for the dissolution of $\mathrm{Cu}_{2} \mathrm{~S}$ in an acid medium, the researchers point out that better results are obtained when working with wastewater compared to seawater due to its higher concentration of chloride. Additionally, it is highlighted that the waste generated when working with wastewater is stable (such as elemental sulfur) and non-polluting.

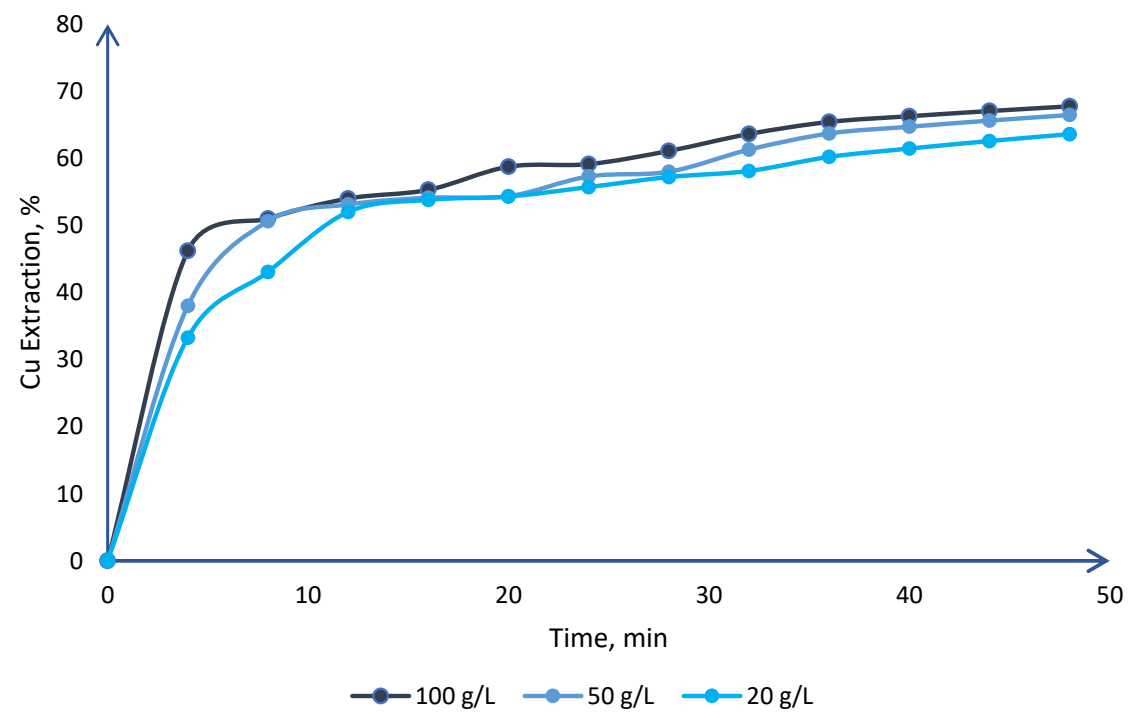

Figure 4. Effect of the chloride concentration in $\mathrm{Cu}_{2} \mathrm{~S}$ solution $\left(\mathrm{T}=25{ }^{\circ} \mathrm{C}, \mathrm{H}_{2} \mathrm{SO}_{4}=0.5 \mathrm{~mol} / \mathrm{L}\right)$ (Modified from: [13]).

The high dissolution rate in the chloride system relative to the sulfated system is attributed to the ability of the chloride ion to stabilize the cuprous ion through the formation of $\mathrm{CuCl}_{3}^{2-}$. In the chloride system, copper can be extracted directly from the chalcocite without causing the oxidation of $\mathrm{Cu}^{+}$to $\mathrm{Cu}^{2+}$. On the other hand, in the sulfated system, $\mathrm{Cu}+$ must be oxidized to $\mathrm{Cu}^{2+}$ on the surface of the particles before copper is released into the solution $[8,13,41,64]$. The addition of chloride ions allows breaking the passivated sulfur layer since an increase in the concentration of chloride ions implies an increase in the redox potential [42], and a higher redox potential generates a thinner layer that makes it easier for chloride ions to generate porosity [13].

\subsection{Effect on Stirring Speed}

The agitation speed in a reactor leaching system decreases the thickness of the boundary layer and maximizes the gas-liquid interface area [67]. This variable is not very significant in copper extraction for tests of the dissolution of $\mathrm{Cu}_{2} \mathrm{~S}$ in an acid-chloride medium. There is a consensus on the part of different authors in previous research $[24,38,61,62,68]$ where it is stated that it is only necessary to stir at a sufficient speed to keep all the chalcocite particles in suspension within the reactor. Additionally, it is important to note that of the various agitation systems used in these investigations it is advisable to work with mechanical agitation since with other systems anomalous results are obtained, for example, in the study carried out by Herreros and Viñals [62] the authors indicate that in their air agitation tests the results were superior under the same operational conditions compared to mechanical agitation tests. This occurred because the air increased the extraction of 
copper. After all, the oxygen reacted with the $\mathrm{CuCl}$ (solid) formed during the leaching process, favoring the formation of $\mathrm{CuCl}^{+}$. On the other hand, Velásquez-Yévenes [68], in his study, mentions that when working with the use of magnetic agitation the mineral is reduced in size due to the abrasion that is generated when it passes under the rotating magnet, generating an increase in the dissolution of chalcocite.

\subsection{Effect on Acid Concentration}

Regarding the acid concentration in a sulfate-chloride system, the findings presented by Dutrizac [69], Cheng and Lawson [24], Senanayake [45], Toro et al. [13], Saldaña et al. [44], and Torres et al. [46] confirm that the concentration of chloride ions in the system is the variable that most influences the kinetics of the dissolution of chalcocite at room temperature, making other operational variables, such as acid concentration, particle size, stirring speed, etc., less relevant. These same results were obtained for other copper sulfides such as covellite [64] and chalcopyrite [70].

Toro et al. [13] performed statistical analysis (ANOVA) for the dissolution of $\mathrm{Cu}_{2} \mathrm{~S}$ in a chloride medium in stirred reactors. For this, the copper extraction was evaluated through the effect of the independent variables with the response surface optimization method (See Table 3). In their results, the researchers indicate that, although sulfuric acid helps to improve the dissolution kinetics of the mineral, the chloride concentration in the system has much more impact on copper extraction, as shown in Figure 5. These results are consistent with those presented by Cheng and Lawson [24], where the researchers mention that a low concentration of $\mathrm{H}_{2} \mathrm{SO}_{4}(0.02 \mathrm{~mol} / \mathrm{L})$ is sufficient to dissolve chalcocite and later phases of it such as djurleite and digenite. However, it is essential to maintain a high concentration of chloride ions since in its absence the dissolution kinetics considerably decrease (first stage) and later the covellite is not dissolved (second stage). On the other hand, a recent study by Torres et al. [46] worked with wastewater at different concentrations of sulfuric acid to dissolve a pure chalcocite mineral. The authors mention that the same results were obtained in their results, even in short periods of time at $\mathrm{H}_{2} \mathrm{SO}_{4}$ concentration ranges between 0.1 and $1 \mathrm{~mol} / \mathrm{L}$ (see Figure 6).

Table 3. Experimental parameters used in statistical analysis [13].

\begin{tabular}{cccc}
\hline Experimental Parameters & Low & Medium & High \\
\hline Time (h) & 4 & 8 & 12 \\
$\mathrm{Cl}^{-}$concentration $(\mathrm{g} / \mathrm{L})$ & 20 & 50 & 100 \\
$\mathrm{H}_{2} \mathrm{SO}_{4}(\mathrm{~mol} / \mathrm{L})$ & 0.5 & 1 & 2 \\
\hline
\end{tabular}

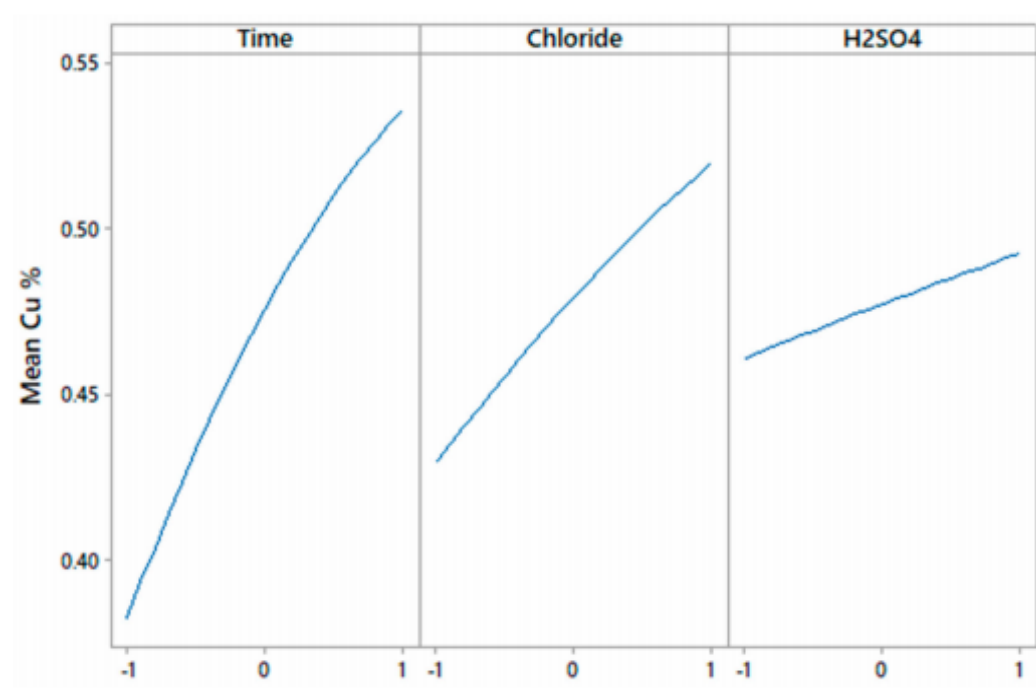

Figure 5. Linear effect graph for the extraction of $\mathrm{Cu}$ from chalcocite in a chloride medium [13]. 


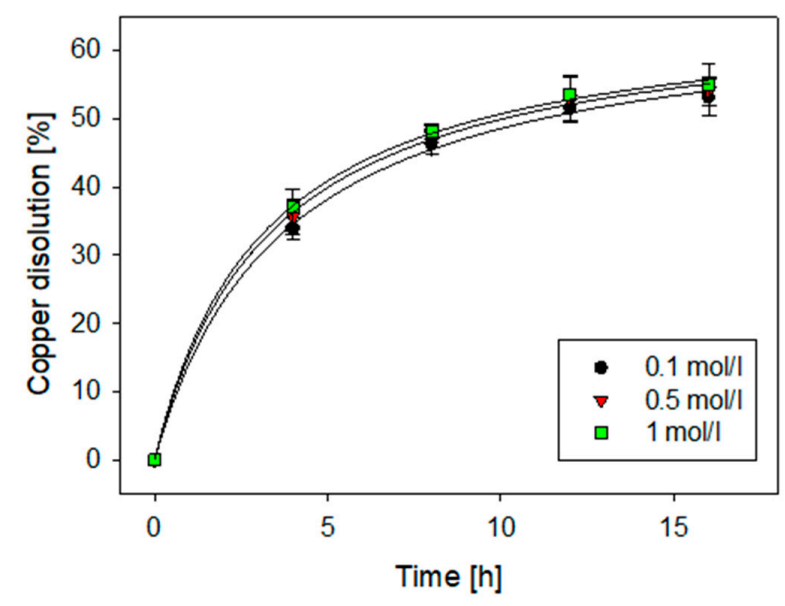

Figure 6. Effect on the $\mathrm{H}_{2} \mathrm{SO}_{4}$ concentration in the $\mathrm{Cu}_{2} \mathrm{~S}$ solution with the use of wastewater $\left(\sim 40 \mathrm{~g} / \mathrm{L} \mathrm{Cl}^{-}\right)[46]$.

\subsection{Particle Size Effect}

The effect of particle size on chalcocite leaching has been studied by different authors; however, these studies have been carried out with relatively small particle sizes: 25 to $4 \mathrm{~mm}$ [71]; $4 \mathrm{~mm}$ to $12 \mu \mathrm{m}$ [62]; 4 to $0.054 \mathrm{~mm}$ [12]; 11 to $63 \mu \mathrm{m}$ [24]; 150 to $75 \mu \mathrm{m} \mathrm{[63];}$ 150 to $106 \mu \mathrm{m}$ [72]. These authors agree that a smaller particle size implies an increase in the dissolution kinetics and the extraction rate in the first leaching stage. But the effect decreases significantly in the second stage. Naderi et al. [71] reported that for fine particle sizes the first stage is controlled by diffusion through the liquid film. In the second stage, the accumulation of the elemental sulfur layer in the solid product, accompanied by a jarosite precipitate, transformed the control mechanism into solid diffusion. Phyo et al. [12] studied the effect on the dissolution kinetics of $\mathrm{Cu}_{2} \mathrm{~S}$ in stirred reactors using an acid medium. In their results, as can be seen in Figure 7a, a significant effect of the particle size is observed in the dissolution of copper, especially in the size of $-0.074+0.054 \mathrm{~mm}$, which in $2.5 \mathrm{~h}$ had already reached $45 \%$ recovery compared to the almost 17 hours it took to achieve the same recovery with $-4+2 \mathrm{~mm}$ particles. In Figure $7 \mathrm{~b}$, the researchers observed a turning point of around $75 \%$ copper dissolution at different times depending on the granulometry and divided the second stage into two sub-stages, indicating that the first sub-stage has a dissolution speed 20 times faster than the second sub-stage.

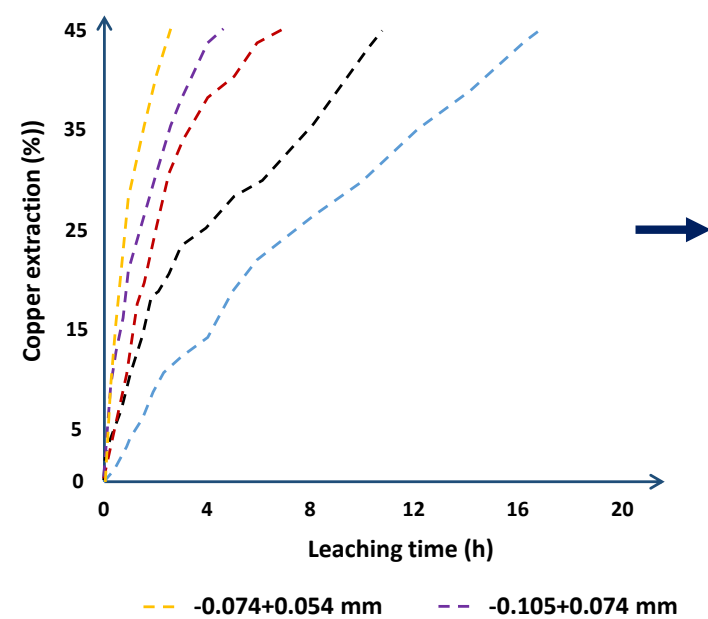

(a) First Stage

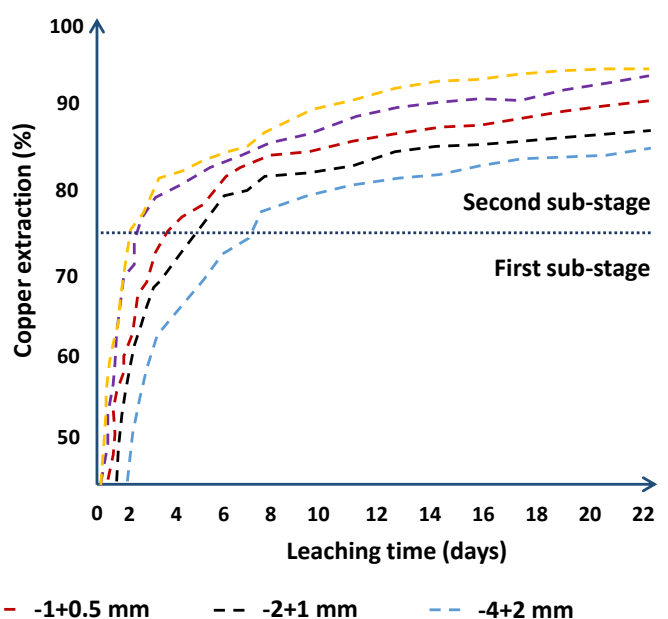

(b) Second stage

Figure 7. $\mathrm{Cu}_{2} \mathrm{~S}$ dissolution at different particle sizes in two different stages: (a) first stage, $(\mathbf{b})$ second stage $\left(\left[\mathrm{Fe}^{3+}\right]=10 \mathrm{~g} / \mathrm{dm}^{3}\right.$, $\mathrm{pH}=1.00-1.50, \mathrm{Eh}=750 \mathrm{mV}$, temperature $=45^{\circ} \mathrm{C}$ ) (Modified from: [12]). 


\subsection{Effect of Temperature}

It is known that temperature is the operational variable that most influences the dissolution of copper sulfide minerals $[43,73,74]$. For the specific case of chalcocite, it becomes a critical parameter during the second stage, being much slower, and can be accelerated with temperature, which indicates that the process is controlled by chemical and/or electrochemical reactions [43,59]. Miki et al. [38] pointed out that the dissolution rate of $\mathrm{CuS}$ is largely independent of the concentration of chloride and $\mathrm{HCl}$ in the ranges of 0.2 to $2.5 \mathrm{~mol} / \mathrm{L}$ and 0.1 to $1 \mathrm{~mol} / \mathrm{L}$, reporting activation energy values of $71.5 \mathrm{~kJ} / \mathrm{mol}$. Therefore, it can be concluded that the process is controlled by a chemical or electrochemical reaction on the surface of the mineral.

In the results presented by Pérez et al. [43] for the dissolution of a pure chalcocite mineral in a chloride medium in a stirred reactor at different temperatures, the authors point out that at temperatures above $65^{\circ} \mathrm{C}$ extractions of copper were close to $40 \%$ in short periods of time (15 $\mathrm{min}$ ) (see Figure 7), which, the researchers concluded, is due to the phase change that governs the first stage of leaching from chalcocite to covellite, which requires low activation energy. More energy is necessary for the second stage to become a copper polysulfide, which requires more demanding conditions to achieve its complete dissolution. In addition, Pérez et al. [43] mentioned that there is good synergy between the chloride concentration in the system and the temperature, since, in their research, they achieved copper extractions of $97 \%$ in 3 hours under the conditions operations that are presented in Figure 8. The research carried out by Ruiz et al. [54] investigated the dissolution of white metal (chalcocite and djurleite) working under similar operational conditions. Without chloride in the system, $55 \%$ extractions were obtained in a time of 5 hours at a temperature of $105^{\circ} \mathrm{C}$.

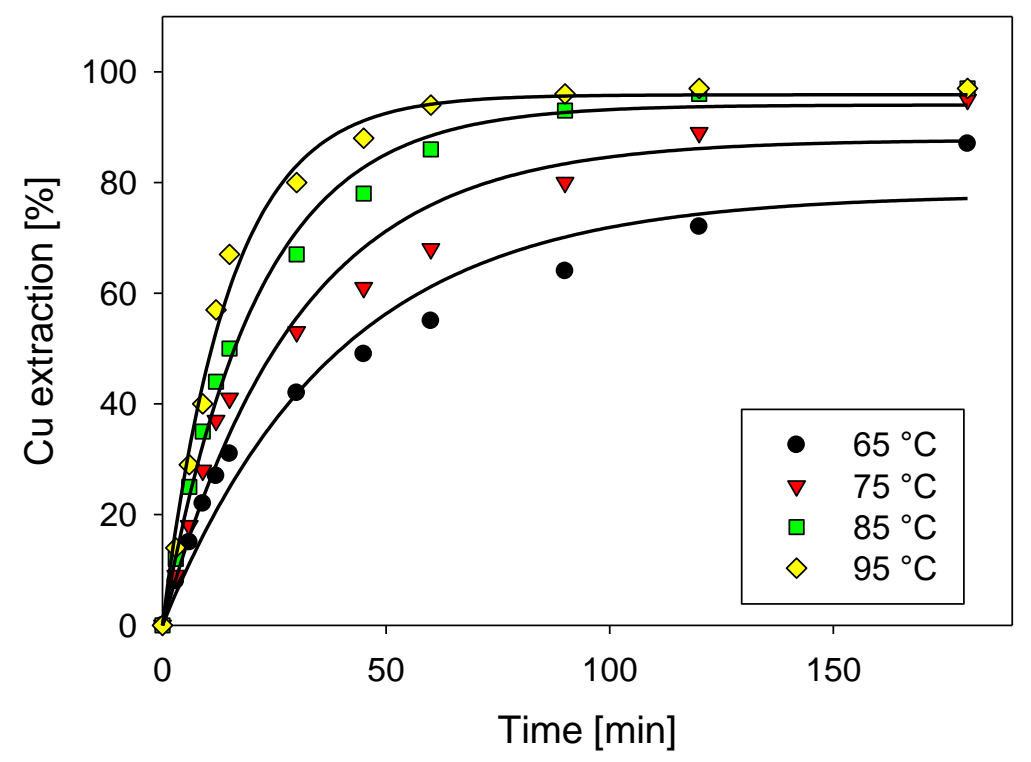

Figure 8. $\mathrm{Cu}_{2} \mathrm{~S}$ dissolution as a function of temperature $\left(0.5 \mathrm{~mol} / \mathrm{L} \mathrm{H}_{2} \mathrm{SO}_{4}\right.$ and $100 \mathrm{~g} / \mathrm{L}$ of $\left.\mathrm{Cl}^{-}\right)$[43].

\subsection{Effect of Redox Potential}

Miki et al. [38] studied the effect of the redox potential in a $\mathrm{Cu}_{2} \mathrm{~S}$ solution (synthetic) with the use of a $0.2 \mathrm{M} \mathrm{HCl}$ solution, $0.2 \mathrm{~g} / \mathrm{L}$ of $\mathrm{Cu}$ (II), and $2 \mathrm{~g} / \mathrm{L}$ of $\mathrm{Fe}$ (III)/Fe (II) at a temperature of $35^{\circ} \mathrm{C}$. The researchers, in their findings, reported that the dissolution of $\mathrm{Cu}_{2} \mathrm{~S}$ occurs rapidly at a potential of $500 \mathrm{mV}$ but then stops when $45 \%$ copper is removed (end of the first stage). For potentials of $550 \mathrm{mV}$, there is then an increase in the dissolution until reaching 50\% extraction of copper. Subsequently, the copper mineral present is mainly covering, which requires potentials of at least $600 \mathrm{mV}$ to be able to dissolve. However, Niu et al. [39] point out that these results were not determined in a range of industrial redox potentials. In their experiments for the dissolution of $\mathrm{Cu}_{2} \mathrm{~S}$, Niu et al. [39] worked in mini 
glass columns ( $30 \mathrm{~cm}$ long and $6 \mathrm{~cm}$ in diameter), adding $\mathrm{Fe}_{2}\left(\mathrm{SO}_{4}\right)_{3}$ as a leaching agent. In their results, the researchers note that the dissolution rate of the second stage of $\mathrm{Cu}_{2} \mathrm{~S}$ leaching was insensitive to the redox potential at moderate temperatures $\left(30-40^{\circ} \mathrm{C}\right)$ in the industrial range of 650-800 $\mathrm{mV}$. In the study conducted by Hashemzadeh et al. [63], the researchers modeled the dissolution kinetics of $\mathrm{Cu}_{2} \mathrm{~S}$ in chloride media using leaching data obtained under fully controlled temperature, $\mathrm{pH}$, and solution potential. In their results, the researchers mentioned that an increase in the chloride concentration and temperature generated an increase in the redox potential, increasing from 680 to $830 \mathrm{mV}$ with the addition of 0.1 chlorides and $3 \mathrm{~mol} / \mathrm{L}$ of $\mathrm{NaCl}$, respectively, and consequently higher dissolution kinetics, mainly in the second leaching stage.

The results obtained from the aforementioned studies are directly related to the formation of a layer of elemental sulfur on the surface of the covellite in the second stage, which decreases with the increase in the potential of the solution; however, the layer in the solid surface is a mixture of sulfur and polysulfides $\left(\mathrm{CuS}_{n}\right)$ [42], where these could be responsible for a slow reaction during this stage.

\subsection{Effect of Oxidizing Agents}

3.7.1. Air

In another study carried out by Cheng and Lawson [24], the effect of aeration on the leaching of chalcocite was seen, but in this case, agitating leaching was carried out, showing that there is no greater contribution. Moreover, by adding a greater flow of air to the system slightly lower recoveries are obtained. This is because the particles adhere to the bubbles generated and are dragged toward the walls of the reactor. On the other hand, in the research carried out by Liu and Granata [75], the effect of aeration was studied by analyzing historical data in two leaching piles of chalcocite as the main mineral present, one with and the other without aeration. In the results, they observed that in leaching in an aerated heap, better results were obtained, but there was only a comparative change after 200 days of leaching with respect to the non-aerated heap. For the aerated pile, from 200 days onward, there was no significant change in copper recovery. This is because aeration is no longer beneficial at this point. After all, we are in the second stage of the dissolution of chalcocite, which is a controlled chemical reaction. Furthermore, the authors mentioned that the total acid consumption per ton of ore processed was higher in the case of the aerated pile, but the net acid consumption per ton of copper produced was the same in both cases.

\subsubsection{Ferric Ions}

The effect of the concentration of ferric ions in the leaching of chalcocite has also been studied. For the first reaction stage, there is a positive effect on the leaching kinetics with an increase in the concentration of ferric ions. When the concentration is lowered, the leaching rate of chalcocite is considerably lower. For the second stage, the ferric ions are not as noticeable as in the first stage. Still, better reaction rates are obtained by increasing their concentration because of the increase generated in the redox potential of the leaching solution $[24,65,72]$.

\subsection{3. $\mathrm{MnO}_{2}$}

The use of $\mathrm{MnO}_{2}$ as an oxidizing agent in chloride media has recently been studied for secondary and primary sulfides $[46,70,76-78]$ where positive results have been obtained in the dissolution of copper. For example, for a mineral refractory to conventional processes such as chalcopyrite, in the study carried out by Toro et al. [70] it was possible to extract $77 \%$ of copper at room temperature when working at high concentrations of $\mathrm{MnO}_{2}(4 / 1$ and 5/1) and chloride ( $\sim 40 \mathrm{~g} / \mathrm{L})$, which allowed maintaining of the redox potential values between 580 and $650 \mathrm{mV}$. For the specific case of chalcocite, Torres et al. [46] worked under the same operational conditions as Toro et al. [13] (see Table 4). In their results, Torres et al. (2020a) showed that incorporating $\mathrm{MnO}_{2}$ at low concentrations significantly 
improves the dissolution of chalcocite in short periods, which is important in continuous leaching operations.

Table 4. Comparison between studies for the dissolution of chalcocite in chloride media, with and without the addition of $\mathrm{MnO}_{2}$.

\begin{tabular}{ccc}
\hline Experimental Conditions and Results & {$[13]$} & [46] \\
\hline Temperature $\left({ }^{\circ} \mathrm{C}\right)$ & 25 & 25 \\
Particle size of $\mathrm{Cu}_{2} \mathrm{~S}(\mu \mathrm{m})$ & $-147+104$ & $-147+104$ \\
$\mathrm{H}_{2} \mathrm{SO}_{4}$ concentration $(\mathrm{mol} / \mathrm{L})$ & 0.5 & 0.5 \\
$\mathrm{MnO}_{2} / \mathrm{Cu}_{2} \mathrm{~S}$ ratio $(\mathrm{w} / \mathrm{w})$ & - & $0.25 / 1$ \\
Dissolution in seawater after $4 \mathrm{~h}(\%)$ & 32.8 & 35.6 \\
Dissolution in reject brine after $4 \mathrm{~h}(\%)$ & 36 & 40 \\
Dissolution in seawater after $48 \mathrm{~h}(\%)$ & 63.4 & 64.7 \\
Dissolution in reject brine after $48 \mathrm{~h}(\%)$ & 64.6 & 66.2 \\
\hline
\end{tabular}

\section{Conclusions}

Among the various leaching processes to treat chalcocite, chloride media show better results and have greater industrial relevance. This is because of the positive results in copper extraction, low cost, and the possibility of working with seawater. However, chalcocite leaching is a process that occurs in two stages, which must be evaluated individually according to the different operational parameters that can be tested in the process.

In general:

Working in chloride media favors the dissolution of $\mathrm{Cu}_{2} \mathrm{~S}$, accelerating the leaching kinetics in the first stage and making possible the dissolution reaction in the second stage. This is mainly due to two reasons: (i) the chloride ions in the system allow the cuprous ions to be stabilized through the formation of $\mathrm{CuCl}_{3}{ }^{2-}$, allowing the copper to be extracted directly from $\mathrm{Cu}_{2} \mathrm{~S}$ without prior oxidation of $\mathrm{Cu}^{+}$to $\mathrm{Cu}^{2+}$; (ii) the chloride ions promote the formation of long crystals that allow the penetration of the reagent through the passivating layer. Furthermore, the concentration of chloride ions is the variable that most influences the dissolution kinetics of $\mathrm{Cu}_{2} \mathrm{~S}$ at room temperature, making other operational variables, such as acid concentration, particle size, stirring rate, and addition of other oxidizing agents (air, ferric ions, etc.), less relevant.

Evaluating by stage:

The first stage of leaching occurs quickly, requiring low activation energy $(4-25 \mathrm{~kJ} / \mathrm{mol})$ in the unreacted core model, via a controlled reaction by diffusion of the oxidant on the mineral surface, while reaction 2 is much slower and requires higher activation energy $(71.5-72 \mathrm{~kJ} / \mathrm{mol})$, being a stage controlled by chemical reaction. During the second stage, in the first instance, it is possible to oxidize the covellite in a wide range of chloride concentrations or redox potentials (up to $75 \%$ extraction of $\mathrm{Cu}$ ). Subsequently, $\mathrm{CuS}_{2}$ is formed, which to be oxidized it is necessary to work at high concentrations of chloride $(>2.5 \mathrm{~mol} / \mathrm{L})$ and/or increase the system's temperature. This is because to dissolve covellite it is necessary to increase the redox potential of the system $(>650 \mathrm{mV})$, which in turn decreases the thickness of the elemental sulfur layer on the mineral surface, facilitating chloride ions to generate a better porosity of this. Furthermore, it is important to note good synergy between the chloride concentration in the system and the temperature. The operational parameters impact differently in each of the stages, as can be seen below in Table 5: 
Table 5. Impact of the different operational parameters on the dissolution of $\mathrm{Cu}_{2} \mathrm{~S}$.

\begin{tabular}{|c|c|c|}
\hline Parameters & First Stage & Second Stage \\
\hline Chloride concentration & Increases dissolution kinetics & Help prevent passivation \\
\hline Stirring rate & It is not relevant & It is not relevant \\
\hline \multirow[t]{2}{*}{ Acid concentration } & $\begin{array}{l}\text { A low concentration of } \mathrm{H}_{2} \mathrm{SO}_{4}(0.02 \mathrm{~mol} / \mathrm{L}) \text { is } \\
\text { sufficient to dissolve the mineral. }\end{array}$ & \multirow[t]{2}{*}{ Increases dissolution kinetics } \\
\hline & $\begin{array}{l}\text { The same results are obtained between } 0.1 \text { and } \\
\qquad 1 \mathrm{~mol} / \mathrm{L} \text { of } \mathrm{H}_{2} \mathrm{SO}_{4} \text {. }\end{array}$ & \\
\hline Particle size & Increase in dissolution kinetics. & Slight increase in dissolution kinetics \\
\hline \multirow{2}{*}{ Temperature } & \multirow{2}{*}{ Significantly accelerates dissolution } & Significantly accelerates dissolution \\
\hline & & Helps prevent passivation \\
\hline Redox potential & Low redox potential is required $(\geq 500 \mathrm{mV})$ & High redox potential values are required $(>650 \mathrm{mV})$ \\
\hline Oxidizing agents (air, $\mathrm{Fe}^{3+}, \mathrm{MnO}_{2}$ ) & $\begin{array}{l}\text { Increases dissolution kinetics by adding } \\
\text { low concentrations }\end{array}$ & $\begin{array}{l}\text { Increases dissolution kinetics, but only at } \\
\text { high concentrations }\end{array}$ \\
\hline
\end{tabular}

Finally, it is concluded that the most optimal way to extract copper from chalcocite is, during the first stage, to work at high concentrations of chloride (50-100 g/L) and low concentrations of sulfuric acid $(0.5 \mathrm{~mol} / \mathrm{L})$ at a temperature environment. Other variables become irrelevant during this stage if the concentration of chloride ions in the system is high. In the second stage, it is necessary to increase the temperature of the system (moderate temperatures) or incorporate a high concentration of some oxidizing agent to avoid the passivation of the mineral.

Author Contributions: N.T., D.T. and K.P. contributed in research and wrote paper, C.M., M.S. and E.G. contributed with research, review and editing. All authors have read and agreed to the published version of the manuscript.

Funding: This research received no external funding.

Acknowledgments: Kevin Pérez acknowledges the infrastructure and support of Doctorado en Ingeniería de Procesos de Minerales of the Universidad de Antofagasta. Carlos Moraga acknowledges the support of Centro Tecnológico de Conversión de Energía of the University of Talca.

Conflicts of Interest: The authors declare no conflict of interest.

\section{References}

1. Bogdanović, G.D.; Petrović, S.; Sokić, M.; Antonijević, M.M. Chalcopyrite leaching in acid media: A review. Metall. Mater. Eng. 2020, 26, 177-198. [CrossRef]

2. Phuong Thao, N.T.; Tsuji, S.; Jeon, S.; Park, I.; Tabelin, C.B.; Ito, M.; Hiroyoshi, N. Redox potential-dependent chalcopyrite leaching in acidic ferric chloride solutions: Leaching experiments. Hydrometallurgy 2020, 194, 105299. [CrossRef]

3. Taboada, M.E.; Hernández, P.C.; Padilla, A.P.; Jamett, N.E.; Graber, T.A. Effects of Fe+2 and Fe+3 in Pretreatment and Leaching on a Mixed Copper Ore in Chloride Media. Metals 2021, 11, 866. [CrossRef]

4. Turan, M.D.; Sarı, Z.A.; Nizamoğlu, H. Pressure leaching of chalcopyrite with oxalic acid and hydrogen peroxide. J. Taiwan Inst. Chem. Eng. 2021, 118, 112-120. [CrossRef]

5. Dutrizac, J. Elemental sulphur formation during the ferric chloride leaching of chalcopyrite. Hydrometallurgy 1990, 23, 153-176. [CrossRef]

6. O'Connor, G.M.; Eksteen, J.J. A critical review of the passivation and semiconductor mechanisms of chalcopyrite leaching. Miner. Eng. 2020, 154, 106401. [CrossRef]

7. Ram, R.; Coyle, V.E.; Bond, A.M.; Chen, M.; Bhargava, S.K.; Jones, L.A. A scanning electrochemical microscopy (SECM) study of the interfacial solution chemistry at polarised chalcopyrite (CuFeS2) and chalcocite (Cu2S). Electrochem. Commun. 2020, 115, 106730. [CrossRef]

8. Torres Albornoz, D.A. Copper and Manganese Extraction Through Leaching Processes, Universidad Politécnica de Cartagena. 2021. Available online: https:/ / repositorio.upct.es/bitstream/handle/10317/9373/data_C.pdf? sequence=1\&isAllowed=y (accessed on 1 October 2021).

9. Hidalgo, T.; Verrall, M.; Beinlich, A.; Kuhar, L.; Putnis, A. Replacement reactions of copper sulphides at moderate temperature in acidic solutions. Ore Geol. Rev. 2020, 123, 103569. [CrossRef] 
10. Domic, E.M. A Review of the Development and Current Status of Copper Bioleaching Operations in Chile: 25 Years of Successful Commercial Implementation. In Biomining; Springer: Berlin/Heidelberg, Germany, 2007; pp. 81-95.

11. Ghorbani, Y.; Becker, M.; Mainza, A.; Franzidis, J.-P.; Petersen, J. Large particle effects in chemical/biochemical heap leach processes-A review. Miner. Eng. 2011, 24, 1172-1184. [CrossRef]

12. Phyo, H.A.; Jia, Y.; Tan, Q.; Zhao, S.; Liang, X.; Ruan, R.; Niu, X. Effect of particle size on chalcocite dissolution kinetics in column leaching under controlled Eh and its implications. Physicochem. Probl. Miner. Process. 2020, 56, 676-692. [CrossRef]

13. Toro, N.; Briceño, W.; Pérez, K.; Cánovas, M.; Trigueros, E.; Sepúlveda, R.; Hernández, P. Leaching of pure chalcocite in a chloride media using sea water and waste water. Metals 2019, 9, 780. [CrossRef]

14. Watling, H.R. The bioleaching of sulphide minerals with emphasis on copper sulphides-A review. Hydrometallurgy 2006, 84, 81-108. [CrossRef]

15. Dunn, J.G.; Ginting, A.R.; O'Connor, B. A thermoanalytical study of the oxidation of chalcocite. J. Therm. Anal. 1994, 41, 671-686. [CrossRef]

16. Evans, H.T. The crystal structures of low chalcocite and djurleite. Zeitschrift Krist.-Cryst. Mater. 1979, 150, 299-320. [CrossRef]

17. Reddy, S.L.; Fayazuddin, M.; Frost, R.L.; Endo, T. Electron paramagnetic resonance and optical absorption spectral studies on chalcocite. Spectrochim. Acta Part A Mol. Biomol. Spectrosc. 2007, 68, 420-423. [CrossRef]

18. Tanda, B.C.; Eksteen, J.J.; Oraby, E.A. Kinetics of chalcocite leaching in oxygenated alkaline glycine solutions. Hydrometallurgy 2018, 178, 264-273. [CrossRef]

19. Wang, L.-W. High Chalcocite Cu2S: A Solid-Liquid Hybrid Phase. Phys. Rev. Lett. 2012, 108, 085703. [CrossRef] [PubMed]

20. Kang, J.; Lee, J.Y. Production of chalcocite by selective chlorination of chalcopyrite using cuprous chloride. Miner. Metall. Process. 2017, 34, 76-83. [CrossRef]

21. Parikh, R.S.; Liddell, K.C. Mechanism of anodic dissolution of chalcocite in hydrochloric acid solution. Ind. Eng. Chem. Res. 1990, 29, 187-193. [CrossRef]

22. Wu, B.; Yang, X.; Wen, J.; Wang, D. Semiconductor-Microbial Mechanism of Selective Dissolution of Chalcocite in Bioleaching. ACS Omega 2019, 4, 18279-18288. [CrossRef]

23. Castillo, J.; Sepúlveda, R.; Araya, G.; Guzmán, D.; Toro, N.; Pérez, K.; Rodríguez, M.; Navarra, A. Leaching of white metal in a $\mathrm{NaCl}-\mathrm{H} 2 \mathrm{SO} 4$ system under environmental conditions. Minerals 2019, 9, 319. [CrossRef]

24. Cheng, C.Y.; Lawson, F. The kinetics of leaching chalcocite in acidic oxygenated sulphate-chloride solutions. Hydrometallurgy 1991, 27, 249-268. [CrossRef]

25. Dunn, J.G.; Ginting, A.; O'Connor, B.H. Quantitative determination of phases present in oxidised chalcocite. J. Therm. Anal. 1997, 50, 51-62. [CrossRef]

26. Posfai, M.; Buseck, P.R. Djurleite, digenite, and chalcocite: Intergrowths and transformations. Am. Mineral. 1994, 79, 308-315.

27. Saldaña, M.; Neira, P.; Flores, V.; Robles, P.; Moraga, C. A Decision Support System for Changes in Operation Modes of the Copper Heap Leaching Process. Metals 2021, 11, 1025. [CrossRef]

28. Bampole, D.L.; Luis, P.; Mulaba-Bafubiandi, A.F. Sustainable copper extraction from mixed chalcopyrite-chalcocite using biomass. Trans. Nonferrous Met. Soc. China 2019, 29, 2170-2182. [CrossRef]

29. Bostelmann, H.; Southam, G. The biogeochemical reactivity of phosphate during bioleaching of bornite-chalcocite ore. Appl. Geochem. 2019, 104, 193-201. [CrossRef]

30. Kang, J.; Qiu, G.; Gao, J.; Wang, H.; Wu, X.; Ding, J. Bioleaching of chalcocite by mixed microorganisms subjected to mutation. J. Cent. South Univ. Technol. 2009, 16, 218-222. [CrossRef]

31. Leahy, M.J.; Davidson, M.R.; Schwarz, M.P. A model for heap bioleaching of chalcocite with heat balance: Bacterial temperature dependence. Miner. Eng. 2005, 18, 1239-1252. [CrossRef]

32. Leahy, M.J.; Davidson, M.R.; Schwarz, M.P. A model for heap bioleaching of chalcocite with heat balance: Mesophiles and moderate thermophiles. Hydrometallurgy 2007, 85, 24-41. [CrossRef]

33. Petersen, J.; Dixon, D.G. The dynamics of chalcocite heap bioleaching. In Hydrometallurgy; Young, C., Alfantazi, A., Anderson, C., James, A., Dreisinger, D.B., Harris, B., Eds.; In Proceedings of the 5th International Symposium Honoring Professor Ian M. Ritchie; TMS Publishers: Vancouver, BC, Canada, 2003.

34. Petersen, J.; Dixon, D.G. Modeling and Optimization of Heap Bioleach Processes. In Biomining; Springer: Berlin/Heidelberg, Germany, 2007; pp. 153-176.

35. Wu, B.; Wen, J.-K.; Chen, B.-W.; Yao, G.-C.; Wang, D.-Z. Control of redox potential by oxygen limitation in selective bioleaching of chalcocite and pyrite. Rare Met. 2014, 33, 622-627. [CrossRef]

36. Zhang, Y.; Zhao, H.; Zhang, Y.; Liu, H.; Yin, H.; Deng, J.; Qiu, G. Interaction mechanism between marmatite and chalcocite in acidic (microbial) environments. Hydrometallurgy 2020, 191, 105217. [CrossRef]

37. Bolorunduro, S.A. Kinetics of Leaching of Chalcocite in Acid Ferric Sulfate Media: Chemical and Bacterial Leaching, University of British Columbia. 1999. Available online: https://open.library.ubc.ca/soa/cIRcle/collections/ubctheses/831/items/1.0078730 (accessed on 1 October 2021).

38. Miki, H.; Nicol, M.; Velásquez-Yévenes, L. The kinetics of dissolution of synthetic covellite, chalcocite and digenite in dilute chloride solutions at ambient temperatures. Hydrometallurgy 2011, 105, 321-327. [CrossRef]

39. Niu, X.; Ruan, R.; Tan, Q.; Jia, Y.; Sun, H. Study on the second stage of chalcocite leaching in column with redox potential control and its implications. Hydrometallurgy 2015, 155, 141-152. [CrossRef] 
40. Palencia, I.; Romero, R.; Mazuelos, A.; Carranza, F. Treatment of secondary copper sulphides (chalcocite and covellite) by the BRISA process. Hydrometallurgy 2002, 66, 85-93. [CrossRef]

41. Fisher, W.W.; Flores, F.A.; Henderson, J.A. Comparison of chalcocite dissolution in the oxygenated, aqueous sulfate and chloride systems. Miner. Eng. 1992, 5, 817-834. [CrossRef]

42. Hashemzadeh, M.; Liu, W. The response of sulfur chemical state to different leaching conditions in chloride leaching of chalcocite. Hydrometallurgy 2020, 192, 105245. [CrossRef]

43. Pérez, K.; Jeldres, R.; Nieto, S.; Salinas-Rodríguez, E.; Robles, P.; Quezada, V.; Hernández-Ávila, J.; Toro, N. Leaching of pure chalcocite in a chloride media using waste water at high temperature. Metals 2020, 10, 1-9. [CrossRef]

44. Saldaña, M.; Rodríguez, F.; Rojas, A.; Pérez, K.; Angulo, P. Development of an empirical model for copper extraction from chalcocite in chloride media. Hem. Ind. 2020, 74, 285-292. [CrossRef]

45. Senanayake, G. Chloride assisted leaching of chalcocite by oxygenated sulphuric acid via Cu(II)-OH-Cl. Miner. Eng. 2007, 20, 1075-1088. [CrossRef]

46. Torres, D.; Trigueros, E.; Robles, P.; Leiva, W.H.; Jeldres, R.I.; Toledo, P.G.; Toro, N. Leaching of Pure Chalcocite with Reject Brine and $\mathrm{MnO} 2$ from Manganese Nodules. Metals 2020, 10, 1426. [CrossRef]

47. Muszer, A.; Wódka, J.; Chmielewski, T.; Matuska, S. Covellinisation of copper sulphide minerals under pressure leaching conditions. Hydrometallurgy 2013, 137, 1-7. [CrossRef]

48. Veltman, H.; Pellegrini, S.; Mackiw, V.N. Direct acid pressure leaching of chalcocite concentrate. JOM 1967, 19, 21-25. [CrossRef]

49. Kyle, J.; Aye, K.T.; Breuer, P.; Meakin, R. The dissolution of covellite and chalcocite in cyanide solutions. The dissolution of covellite and chalcocite in cyanide solutions. In Proceedings of the World Gold 2011: 50th Annual Conference of Metallurgists of CIM, Montreal, QC, Canada, 2-5 October 2011; 2011.

50. Shantz, R.; Fisher, W.W. The kinetics of the dissolution of chalcocite in alkaline cyanide solution. Metall. Trans. B 1977, 8, 253-260. [CrossRef]

51. Konishi, Y.; Katoh, M.; Asai, S. Leaching kinetics of copper from natural chalcocite in alkaline Na4EDTA solutions. Metall. Trans. B 1991, 22, 295-303. [CrossRef]

52. Tomášek, J.; Neumann, L. Dissolution of secondary copper sulphides using complex-forming agents (EDTA, EDA). Part II: Chalcocite dissolution in EDTA and EDA. Int. J. Miner. Process. 1982, 9, 41-57. [CrossRef]

53. Herreros, O.; Quiroz, R.; Viñals, J. Dissolution kinetics of copper, white metal and natural chalcocite in $\mathrm{Cl} 2 / \mathrm{Cl}-\mathrm{media}$. Hydrometallurgy 1999, 51, 345-357. [CrossRef]

54. Ruiz, M.C.; Abarzúa, E.; Padilla, R. Oxygen pressure leaching of white metal. Hydrometallurgy 2007, 86, 131-139. [CrossRef]

55. Moraga, G.A.; Jamett, N.E.; Hernández, P.C.; Graber, T.A.; Taboada, M.E. Chalcopyrite Leaching with Hydrogen Peroxide and Iodine Species in Acidic Chloride Media at Room Temperature: Technical and Economic Evaluation. Metals 2021, $11,1567$. [CrossRef]

56. Saldaña, M.; Toro, N.; Castillo, J.; Hernández, P.; Navarra, A. Optimization of the heap leaching process through changes in modes of operation and discrete event simulation. Minerals 2019, 9, 1-13. [CrossRef]

57. COCHILCO. Proyeccion Agua Mineria del Cobre 2019-2030; COCHILCO: Santiago, Chile, 2020; Available online: https:// www.cochilco.cl/Listado\%20Temtico/proyeccion\%20agua\%20mineria\%20del\%20cobre\%202019-2030\%20VF.pdf (accessed on 1 October 2021).

58. Whiteside, L.S.; Goble, R.J. Structural and compositional changes in copper sulfides during leaching and dissolution. Can. Mineral. 1986, 24, 247-258.

59. Ruan, R.; Zou, G.; Zhong, S.; Wu, Z.; Chan, B.; Wang, D. Why Zijinshan copper bioheapleaching plant works efficiently at low microbial activity-Study on leaching kinetics of copper sulfides and its implications. Miner. Eng. 2013, 48, 36-43. [CrossRef]

60. Nicol, M.; Basson, P. The anodic behaviour of covellite in chloride solutions. Hydrometallurgy 2017, 172, 60-68. [CrossRef]

61. Ruiz, M.C.; Honores, S.; Padilla, R. Leaching kinetics of digenite concentrate in oxygenated chloride media at ambient pressure. Metall. Mater. Trans. B 1998, 29, 961-969. [CrossRef]

62. Herreros, O.; Viñals, J. Leaching of sulfide copper ore in a NaCl-H2SO4-O2 media with acid pre-treatment. Hydrometallurgy 2007, 89, 260-268. [CrossRef]

63. Hashemzadeh, M.; Dixon, D.G.; Liu, W. Modelling the kinetics of chalcocite leaching in acidified cupric chloride media under fully controlled $\mathrm{pH}$ and potential. Hydrometallurgy 2019, 189, 105114. [CrossRef]

64. Pérez, K.; Toro, N.; Saldaña, M.; Salinas-Rodríguez, E.; Robles, P.; Torres, D.; Jeldres, R.I. Statistical Study for Leaching of Covellite in a Chloride Media. Metals 2020, 10, 477. [CrossRef]

65. Hashemzadeh, M.; Dixon, D.G.; Liu, W. Modelling the kinetics of chalcocite leaching in acidified ferric chloride media under fully controlled $\mathrm{pH}$ and potential. Hydrometallurgy 2019, 186, 275-283. [CrossRef]

66. Hernández, P. Estudio del Equilibrio Sólido-Líquido de Sistemas Acuosos de Minerales de Cobre Con Agua de Mar, Aplicado A Procesos de Lixiviación, Universidad de Antofagasta. 2013. Available online: https://intranetua.uantof.cl/docs/carreras/tesis_ pia_hernandez.pdf (accessed on 1 October 2021).

67. Schlesinger, M.; King, M.; Sole, K.; Davenport, W. Extractive Metallurgy of Copper, 5th ed.; Elsevier: Amsterdam, The Netherlands, 2011; ISBN 9780080967899.

68. Velásquez-Yévenes, L. The Kinetics of the Dissolution of Chalcopyrite in Chloride Media, Murdoch University. 2009. Available online: https:/ / researchrepository.murdoch.edu.au/id/eprint/475/ (accessed on 1 October 2021). 
69. Dutrizac, J.E. The leaching of sulphide minerals in chloride media. Hydrometallurgy 1992, 29, 1-45. [CrossRef]

70. Toro, N.; Pérez, K.; Saldaña, M.; Jeldres, R.I.; Jeldres, M.; Cánovas, M. Dissolution of pure chalcopyrite with manganese nodules and waste water. J. Mater. Res. Technol. 2019, 9, 798-805. [CrossRef]

71. Naderi, H.; Abdollahy, M.; Mostoufi, N. Kinetics of chemical leaching of chalcocite from low-grade copper ore: Size-distribution behavior. J. Min. Environ. 2015, 6, 109-118. [CrossRef]

72. Toro Villarroel, N.R. Optimización de Parámetros Para la Extracción de Elementos Desde Minerales en Medios Ácido, Universidad Politécnica de Cartagena. 2020. Available online: https:/ / repositorio.upct.es/handle/10317/8504 (accessed on 1 October 2021).

73. Chang, K.; Zhang, Y.; Zhang, J.; Li, T.; Wang, J.; Qin, W. Effect of temperature-induced phase transitions on bioleaching of chalcopyrite. Trans. Nonferrous Met. Soc. China 2019, 29, 2183-2191. [CrossRef]

74. Li, Y.; Kawashima, N.; Li, J.; Chandra, A.P.; Gerson, A.R. A review of the structure, and fundamental mechanisms and kinetics of the leaching of chalcopyrite. Adv. Colloid Interface Sci. 2013, 197, 1-32. [CrossRef]

75. Liu, W.; Granata, G. The Effect of Aeration on Chalcocite Heap Leaching. In Extraction; Davis, B., Moats, M., Wang, S., Gregurek, D., Kapusta, J., Battle, T., Schlesinger, M., Alvear, G., Jak, E., Goodall, G., Eds.; The Minerals, Metals \& Materials Series; Springer: Cham, Switzerland, 2018. [CrossRef]

76. Devi, N.B.; Madhuchhanda, M.; Rao, K.S.; Rath, P.C.; Paramguru, R.K. Oxidation of chalcopyrite in the presence of manganese dioxide in hydrochloric acid medium. Hydrometallurgy 2000, 57, 57-76. [CrossRef]

77. Kowalczuk, P.B.; Manaig, D.O.; Drivenes, K.; Snook, B.; Aasly, K.; Kleiv, R.A. Galvanic leaching of seafloor massive sulphides using $\mathrm{MnO} 2$ in $\mathrm{H} 2 \mathrm{SO} 4-\mathrm{NaCl}$ media. Minerals 2018, 8, 235. [CrossRef]

78. Torres, D.; Ayala, L.; Jeldres, R.I.; Cerecedo-Sáenz, E.; Salinas-Rodríguez, E.; Robles, P.; Toro, N. Leaching Chalcopyrite with High $\mathrm{MnO} 2$ and Chloride Concentrations. Metals 2020, 10, 107. [CrossRef] 